\title{
LEGAL BACKGROUND, TRENDS, AND RECENT DEVELOPMENTS IN THE INVESTMENT OF TRUST FUNDS
}

\author{
Bascom H. Torrance* \\ I \\ Some Counsel from the Cases
}

Some years ago the Trust Division of the American Bankers Association published a pamphlet which bore on its fly-leaf the following words from the historian and legal scholar Josephus: ${ }^{1}$

Let him that hath received any thing in trust for another, take care to keep it as a sacred and divine thing; and let no one invent any contrivance whereby to deprive him that hath intrusted it with him of the same, and this whether he be a man or woman; no, not although he or she were to gain an immense sum of gold. . . .

Not much has happened since the days of Josephus to change this concept of trusteeship. On the contrary much has happened to strengthen and preserve it. In fact, even the word itself has acquired overtones suggestive of the greatest confidence that men repose, the highest fidelity and the best performance that can be found. We severely criticize one who fails his trust; we speak of political office as a public trust, remembering Disraeli's remark that "all power is a trust"; we propose trusteeship with a strong nation or the United Nations for weaker peoples who need guidance and protection. Our coins bear the motto "In God We Trust."

Nearly two thousand years after Josephus one of our foremost judges, the late Benjamin Cardozo, echoed the sentiments of Josephus in words of his own. ${ }^{2}$

A trustee is held to something stricter than the morals of the market place. Not honesty alone, but the punctilio of an honor the most sensitive, is then the standard of behavior.

Between Josephus and Cardozo lies a vast and turbulent history of the deeds and misdeeds of mankind. That the character of trusteeship found such eloquent expression in such early times, when men were not credited generally with too firm or too refined a morality, and that it has survived virtually unchanged through all that has happened since, seems some evidence of its hardihood as a social institution, and perhaps some assurance of its further survival into a troubled future.

*A.B. 1917, Harvard University. Senior investment officer on trusts and estates with City Bank Farmers Trust Company, an affiliate of the National City Bank of New York. Chairman, Trust Investment Study Committee, New York State Bankers Association.

1 The pamphlet of the American Bankers Association was "The Prudent Man Rule for Trust Investment," published in 1942. The words quoted above were part of a longer passage from the works of Josephus quoted by Samuel Freifield of the Steubenville, Ohio, bar, in an article, Investment of Trist Funds, 5 U. OF CrN. L. Rev. I (193I).

"Meinhard v. Salmon, 249 N. Y. 458,464, I65 N. E. 545,546 (1928). 
While the two passages quoted above, especially the latter, touch particularly upon the honor of a trustee, innumerable others in similar vein could be cited by way of amplifying the general standard of conduct required of him. To clear the way for some comment to follow, it may be interesting to recall a few. It is unnecessary, however, to go back to Josephus to find them. We can begin with the year I8 30 , when we were first introduced to that legendary legal character, the prudent man. Simply because it is the foundation of our story, and even at the risk of wearisome repetition, here again is the famous and familiar passage from the decision in Harvard College v. Amory. ${ }^{3}$

All that can be required of a trustee to invest, is, that he conduct himself faithfully and exercise a sound discretion. He is to observe how men of prudence, discretion, and intelligence manage their own affairs, not in regard to speculation, but in regard to the permanent disposition of their funds, considering the probable income, as well as the probable safety of the capital to be invested.

Now it is obvious at once that this classic statement leaves wide room for interpretation. That indeed is its great virtue, as another Massachusetts judge has emphasized nearly one hundred years later $\mathbf{4}^{4}$

Good faith and sound discretion, as these terms ought to be understood by reasonable men of good judgment, were thus made the standard by which the conduct of trustees is to be measured. That is a comprehensive principle. It is wide in its scope. It is not limited to a particular time or a special neighborhood. It is general and inclusive, so that while remaining itself fixed, it may continue to be a safe guide under new financial institutions and business customs, changed commercial methods and practices, altered monetary usages and investment combinations. It avoids the inflexibility of definite classifications of securities, it disregards the optimism of the promoter, and eschews the exuberance of the speculator. It holds fast to common sense and depends on practical experience. It is susceptible of being adapted to whatever conditions may arise in the evolution of society and the progress of civilization.

These are eloquent words, but again their eloquence surpasses their precision. Therefore, for further enlightenment we must go to still other decisions and seek more specific criteria. And in these efforts over the years toward a proper application of the basic rule we find some distinct differences in viewpoint and in practice, best illustrated in the familiar story of the different application given the basic rule in the so-called "prudent rule" states as against the so-called "legal list" states. That a new chapter in this story is being written in the present trend away from legal lists will be commented upon later, but does not remove the fact of historical divergence.

The standard illustration of this divergence in the investment field is the leading New York case of King v. Talbot, ${ }^{5}$ and the precedents which that decision and others like it established. It will be remembered that in Harvard College v. Amory

\footnotetext{
${ }^{3}$ Harvard College v. Amory, 9 Pick. 446, 46I (Mass. I830).

Kimball v. Whitney, 233 Mass. 32I, 33I, I23 N. E. 665,666 (I9I9).

${ }^{8} \mathrm{King}$ v. Talbot, 40 N. Y. 76 (1869).
} 
the court had approved the trustee's action in retaining and investing in certain stocks, holding that they were not improper for a trustee. The New York court some years later, although agreeing as to the basic rule to be applied, took quite a different view as to stocks: ${ }^{6}$

My own judgment, after an examination of the subject, and bearing in mind the nature of the office, its importance, and the considerations, which alone induce men of suitable experience, capacity, and responsibility to accept its usually thankless burden, is, that the just and true rule is, that the trustee is bound to employ such diligence and such prudence in the care and management, as in general, prudent men of discretion and intelligence in such matters, employ in their own like affairs.

This necessarily excludes all speculation, all investments for an uncertain and doubtful rise in the market, and of course everything that does not take into view the nature and object of the trust and the consequences of a mistake in the selection of the investment to be made.

It, therefore, does not follow, that, because prudent men may, and often do, conduct their own affairs with the hope of growing rich, and therein take the hazard of adventures which they deem hopeful, trustees may do the same; the preservation of the fund, and the procurement of a just income therefrom, are primary objects of the creation of the trust itself, and are to be primarily regarded.

The moment the fund is invested in bank, or insurance, or railroad stock, it has left the control of the trustees; its safety and the hazard, or risk of loss, is no longer dependent upon their skill, care, or discretion, in its custody or management, and the terms of the investment do not contemplate that it ever will be returned to the trustee.

If it be said, that, at any time, the trustees may sell the stock (which is but another name for their interest in the property and business of the corporation) and so repossess themselves of the original capital, I reply, that is necessarily contingent and uncertain; and so the fund has been voluntarily placed in a condition of uncertainty....

- This decision is mentioned because of its historical importance. As New York trustees are well aware, later cases, especially where the trust instrument granted broad investment powers, have taken a more liberal view. Yet the prohibition expressed against stocks in King $v$. Talbot subsequently found reflection in the laws governing trust investments not only in New York but in a number of other states, and for many years has been perhaps the major point of difference between the so-called "prudent rule" states, which have followed the Massachusetts doctrine, and the "legal list" states, which in general have followed the doctrine laid down in King $v$. Talbot. As will be mentioned later, the New York law was broadened in I950 to permit stocks under certain limitations, but they are still excluded in a number of other states.

In spite of these historic differences of interpretation, which are gradually and happily disappearing, there is discernible in all the cases and in all the legislation controlling trust investments a fundamental current of agreement. This agreement is found in the strong and persistent emphasis on this elusive and elastic thing we

- $I d$. at 85-86, 88-89. 
have chosen to call prudence, in every sort of situation and with respect to whatever kind of investment may be used. Men may differ in different circumstances as to precisely what prudence is, but successive decisions in different jurisdictions have set at least some broad limits within which it is recognizable and beyond which it vanishes.

To begin with, it has never been "that illimitable potentiality which an unrestrained individual possesses respecting his own property."7 Even in Massachusetts, traditionally one of the most liberal states, the courts have helped to set restrictions. For example: 8

... Trustees in this commonwealth are permitted to invest portions of trust-funds in dividend-paying stocks and interest-bearing bonds of private business corporations, when the corporations have acquired, by reason of the amount of their property and the prudent management of their affairs, such a reputation that cautious and intelligent persons commonly invest their own money in stocks and bonds as permanent investments.

A year or two later, in the neighboring state of Maine, we find a court speaking as follows: ${ }^{9}$

While he [the trustee] must be as diligent and painstaking in the management of the trust estate as the average prudent man is in managing his own estate, he may not always place the trust funds where he, or the average prudent man, would place his own funds.... There are often occurring good business chances in which a man may invest some of his own money without danger of being called imprudent, whatever the result. But it will be generally conceded that a mere business chance or prospect, however promising, is not a proper place for trust funds.

The business may have promised well. The chance of making money and building up a business was probably excellent. The appellant, a man of well-known energy and enterprise, after personal investigation, formed a favorable opinion of the company's prospects. But however favorable and glowing these prospects, we think that in the light of the decisions of the courts, and in the light of general experience, the appellant could and should have seen that he had no authority to invest trust funds in them.

Here the trustee was surcharged for investing in the stock of a relatively new packing and canning company, which had not built up a strong financial position or established earnings record.

A similar view, and a similar result of investment in a company of insufficient financial standing, is found in the New York case of Matter of Hall: ${ }^{10}$

7 Dumaine v. Dumaine, 30I Mass. 214, 220, I6 N. E. 2d 625, 629 (1938).

Appeal of Dickinson, I52 Mass. 184, 187-188, 25 N.E. 99, 100 (1890). (Italics supplied.) This decision dealt not only with the unseasoned character of the investment, but also with the question of diversification. One investment in stock of the Union Pacific Railway was approved, a second investment was disapproved.

${ }^{9}$ Mattocks v. Moulton, 84 Me. 55I-552, 555, 24 Atl. 1004, 1006, 1007 (I892).

${ }^{10}$ Matter of Hall, I64 N. Y. I96, 200, 58 N.E. II, 12 (I900). (Italics supplied.) Here the trustees, acting under broad powers conferred by the will, merged an umbrella company left by the testator into a newly formed umbrella "trust," taking stock in the new and untried company in exchange for the assets of the testator's company. They were surcharged for loss. 
If the trustees had invested in the stock of a railroad, manufacturing, banking, or even business corporation, which, by its successful conduct for a long period of time, had achieved a standing in commercial circles and acquired the confidence of investors, their conduct would have been justified, although the investment proved unfortunate.

These general views were repeated years later in Matter of Winburn:11

Executors need not wait on the stock market, but may properly be guided by the tests to be applied, which are: What has been the history of the companies during a period of years? Have they paid regular dividends of regular amounts? Have they a proper capital structure? Are they wisely officered? Has a successful business continued over a period of time? Have they achieved a standing in commercial circles?

And again in New York there is the warning: $:^{12}$

Persons who handle trust funds should not be carried away by a speculative wave and allow their desire for profit and apparent large return on the investment for a short time to run away entirely with their sound judgment based upon experience of a long term of years during recurring periods of prosperity and depression.

An early English case often cited held that "the duty of a trustee is not to take such care only as a prudent man would take if he had only himself to consider; the duty rather is to take such care as an ordinary prudent man would take if he were minded to make an investment for the benefit of other people for whom he felt morally bound to provide."13

In Hart's Estate a Pennsylvania court spoke as follows: $:^{14}$

But a prudent man, with his own estate, with the object of making money, expecting his investment to largely enhance in value, may take greater risks. It is nobody's business but his own. He calculates probabilities of success or failure, and takes the chances. If successful, foresight and business shrewdness are attributed to him; if failure happens, then speculation, or something worse. But he is no more imprudent in the one case than in the other. Future events are, from their very nature, not definitely foreseeable, and a prudent man has a perfect right to venture his own money on a calculation of business chances. All fortunes are accumulated by the exercise of just that sort of very common "prudence. But with a trustee the case is different. He has all the knowledge, foresight, and judgment of the business man; but the money to invest is not his own, but belongs to others. It is his plain duty, if he would safely keep it, to minimize risks. He is not bound to have more prudence than the other, but he must utilize his in avoiding risks which the one who owes no duty to others is free to take. In the one case, in view of probable favorable results, prudence says, "Take the risk," in the other, in view of very possible disaster, prudence says, "Take not the risk."

Similar views are found in Estate of Cook, where a Delaware judge added his own observations: $:^{15}$

${ }^{11}$ Matter of Winburn, I40 Misc. 18, 22, 249 N. Y. Supp. 758, 763 (Surr. Ct. 193 T).

${ }_{12}$ Matter of Jacobs, 152 Misc. 139, 142, 273 N. Y. Supp. 279, 282-283 (Surr. Ct. 1934).

${ }^{13}$ In te Whiteley, 33 Ch. Div. 347, 355 (1886), affd, stib nom. Learoyd v. Whiteley, 12 App. Cas. $727(x 887)$.

14 In re Hart's Estate, 203 Pa. 480, 484, 53 Atl. 364, 366 (1902).

${ }^{15}$ In re Cook's Estate, 20 Del. Ch. 123, I25, I7I Atl. 730, 731 (1934). 
The first is, that the external standard of "such care and skill as a man of ordinary prudence would exercise in dealing with his own property" is not the standard he would use in dealing with his own property if he had only himself to consider. . . . In other words he must take no risks which would not be taken by an ordinarily prudent man who is trustee of another person's property.

The next observation to be made is that the primary object to be attained by a trustee in the matter of investing the funds confided to his control is their safety.

Cases such as the three just cited not only agree with the others in their emphasis on conservatism, but have often been interpreted as going further and drawing a distinction between a prudent man and a prudent trustee. It is doubtful whether this was the intention of the courts, or is a proper interpretation of the basic rule. To say that a trustee must exercise the prudence of a trustee is to talk in circles. What is the standard for a prudent trustee? The sound view of the prudent man rule, if it is to be our standard, seems to be substantially as stated in King v. Talbotnamely, that a trustee must employ such diligence and prudence "as in general prudent men of discretion and intelligence in such matters employ in their own like affairs."16 The words "like affairs" suggest that all the courts have meant to say is that the motives and purposes of a trustee must be those of prudent men who are seeking, not speculative gains, but reasonable income and conservation of their capital. $^{17}$

The pronouncements quoted are only a few from among the many with which trustees and lawyers are familiar. Although certainly no precise blueprint, they at least provide some important guiding principles. Moreover, as time has passed certain things have become plain. In addition to the general standard of care demanded of him in making investments, a trustee must be diligent in his attention to his investments after they are made. He must inform himself of what other prudent men are doing, remembering, as Judge Woodruff said in King v. Talbot, that the rule "imposes the duty to observe and know, or learn, what such prudence dictates in the matter in hand."18 The cases cited plainly bar investments for the "short haul," or primarily for spectulative gains, investments in new, untried or weak enterprises, or enterprises concerning which there is insufficient information; investments of any character concerning which a prudent man may have a question as to security and stability. Admittedly, in many instances, as the court said in Kimball v. Reding, in what may be regarded as judicial understatement, "the question as to what are good and proper securities is left somewhat at large, and must be conceded

${ }^{10} 40$ N. Y. 76,86 (I869). (Italics supplied.)

17 Substantially the view expressed by Professor Scott: "It is not enough that the trustee in investing trust funds uses care and skill. A man of business in investing his own funds, or even a speculator, may use a high degree of care and skill in attempting to increase the value of his estate. In so doing, however, he may take risks which a trustee is not justified in taking. The primary purpose of a trustee should be to preserve the trust estate, while receiving a reasonable amount of income, rather than to take risks for the purpose of increasing the principal or income. In other words, a trustee must be not merely careful and skillful but also cautious." II ScoTr on TRusrs \$227.3 (1939).

${ }^{18} 40$ N. Y. $76,86(1869)$. 
to be not without its difficulties."19 At just what point does an investment pass from the new or untried category into the seasoned class? How long and how strong a record must it have? These are questions as to which even prudent men may well differ, especially in borderline cases, and here, incidentally, we have in large part the explanation of our legal lists. It was to resolve just such questions that some states deemed it advisable to set precise statutory tests for trust investments. They had their uses during a certain stage of our economic development, but more and more, as we shall see later, they are passing from the scene.

The one thing above all that emerges clearly and without question from the cases cited and others like them is the legally established concept of the trustee as a conserver. Yet there are those who criticize this concept, claiming that it has received exaggerated importance, and there are others who raise questions as to just what conservation is. These are views and questions which deserve attention. Perhaps they can be somewhat simplified, even if not completely resolved.

To begin with, the position of the trustee as a conserver, rather than a creator, of capital, as indicated in the cases cited, is not just an accident or a whim. There are excellent practical as well as legal reasons why the emphasis is where it is. If we lose principal, we generally lose income, sometimes permanently. Furthermore, if all investments were successful, if there had never been any losses or any depreciated trust funds, there would be no need for this emphasis on conservation; it would have died away long ago. It arose out of the experience and mistakes of investors and trustees over many generations, investors and trustees who no doubt regarded themselves as prudent men.

It is sometimes argued that conservation derived its original importance from the early days of trusteeship, when the corpus of a trust was a res, or thing, such as land, but that it has acquired a vastly exaggerated importance in the transition of the res to a quantum, or something with marketable or money value. This claim of exaggerated importance is then associated with the trustee's duty to account, which leads to an understandable desire to maintain the variable value of his quantum, and the further argument is made that trustees have followed a conservative course for two reasons, first, because it is easy, and second, because of the fear of surcharge.

As for the first charge, it will be hard to convince a practicing trustee, accustomed to dealing with the problems of his clients in days of low incomes and a high cost of living, that the conservative course is always the easiest course. Trustees are like other people; they are human and sympathetic, and they like to please. Far from being easy, the conservative course is often the very hardest to follow and to sell. By its very nature it is generally less profitable, certainly less spectacular, than a more venturesome course, and for that reason is seldom popular, especially in times of great prosperity and rising markets. Its virtues appear when times are not so prosperous. As for the second charge, it seems greatly overdone. It may be true

${ }^{10}$ Kimball v. Reding, 3x N. H. 352, 374, 64 Am. Dec. 333, 336-337 (1855). 
that practitioners in strict jurisdictions are inclined to regard the surcharge problem somewhat less lightly than their colleagues in more liberal jurisdictions where the courts are known for their sympathetic treatment of trustees, and where exculpatory clauses are sometimes used. That the problem is there need not be blinked; it arises out of the high degree of accountability to which trustees are properly held, and has been described as "a type of litigation which sprouts from economic depression as naturally as weeds from loam."20 True, instances of actual surcharge are relatively few, but the loss, the waste, in these proceedings is not in the actual dollar damages that are occasionally awarded, but in the time, expense, and injured public relations involved in the litigation. Moreover, on the whole, the courts seem usually to arrive at fair verdicts. It must be remembered that judges are human, and that many of them are without extensive investment experience. It might also be noted that one of our most eminent jurists, Judge Learned Hand, lately retired as Chief Judge of the United States Court of Appeals of the Second Circuit, has been quoted as saying that as a litigant he would "dread a law suit beyond almost anything short of sickness and death." Some harsh decisions there have been, some reversible errors; here and there a ruling or a dictum that has drawn sharp criticism from lawyers, ${ }^{21}$ but along with them, a considerable number of decisions evidencing a practical, understanding, and impartial attitude. The courts in fact have often been far more tolerant than beneficiaries in judging trustees, realizing that their judgments were generally rendered with the benefit of hindsight. Even in the Harvard College case the court observed $:^{22}$

Trustees are justly and uniformly considered favorably, and it is of great importance to bereaved families and orphans, that they should not be held to make good losses in the depreciation of stocks or the failure of the capital itself, which they held in trust, provided they conduct themselves honestly and discreetly and carefully, according to the existing circumstances, in the discharge of their trusts. If this were held otherwise, no prudent man would run the hazard of losses which might happen without any neglect or breach of good faith.

And Judge Woodruff in King $v$. Talbot, referred to "the considerations which alone induce men of suitable experience, capacity and responsibility" to accept the "usually thankless burden" of trusteeship. Consider, too, rulings such as these:

If foresight were generally as good as hindsight, it would be a far more pleasant world in which to live. ${ }^{23}$

A wisdom developed after an event and having it and its consequences as a source is a standard no man should be judged by. ${ }^{24}$

The trend of a market is notoriously hard to discover except in retrospect. At every level skilled observers are apt to disagree as to its probable course. ${ }^{25}$

${ }^{20}$ Moore, A Rationalization of Trust Surcharge Cases, 96 U. of PA. L. Riv. 647 (1948).

${ }^{21}$ See Haggerty, Conflicting Interests of Estate Fiduciaries in New York and the "No Further Inquiry" Rule, 18 FORD. L. REv. I (1949).

${ }_{22}$ Harvard College v. Amory, 9 Pick. 446, 465 (Mass. $x 830$ ).

${ }^{23}$ Matter of Winburn, I40 Misc. 18, 23, 249 N. Y. Supp. 758, 765 (Surr. Ct. I93I).

24 Costello v. Costello, 209 N. Y. 252, 262, 103 N. E. I48, 162 (1913).

${ }^{25}$ First National Bank of Boston v. Truesdale Hospital, 288 Mass. 35, 46, I92 N. E. I50, I53 (I934). 
In the opinion of the present writer it is seriously to be questioned, on the basis of many discussions with trust officers and much observation of trust investing, whether the fear of surcharge is a controlling or even an important cause of action in any appreciable number of trust decisions. If a proposed action is of a nature to suggest liability for surcharge, a trustee will naturally avoid it and advise against it from the very beginning. Objections to accountings and claims for surcharge most often arise years later, out of actions which no one, trustee or beneficiary, had reason to question at the time.

Extreme advocates of the Massachusetts rule couple their criticism of what they claim is undue concern over the variable value of a quantum with pleas for a far more liberal theory of trusteeship, looking to the active and aggressive management of practically every form of property, including private businesses and close corporations under "consensual" agreements granting extremely broad powers. Needless to say, there is some division of opinion among trustees over such a view, even in Massachusetts itself, the stronghold of the prudent rule and its most ardent advocates. $^{26}$ Assuming that competent personnel would be available for dealing with a vast variety and number of new problems, there is still a small matter of expense, for trusteeship, under the present schedule of compensation in many jurisdictions, is notoriously not among the most profitable professions. Presumably, the consensual agreements above referred to could meet difficulties of this kind, but the statutory fees now in effect in most states have been set with quite a different type of trust administration in view.

The advocates of this theory of trusteeship in its extreme form admit that the existing legal framework, of which the decisions mentioned above are an example, presents some obstacles. But they regard this legal background simply as an "agglomeration of man-made law," and suggest that we anticipate the courts by creating new situations which will require new law. Within limits, of course, that is often the way new law is made. But the spirit of adventure has found little sanction in trusteeship, and the courts are not likely to look kindly upon those who do not take seriously the rules of conduct they have laid down.

There is another approach to this question of conservation. It begins with the simple fact that it is a custom not unknown among prudent men to divide their careers into two broad periods. The first, and usually longer, period covers the years of more active participation in business or the professions. These are the years of aggressive search for fame or fortune, a period when setbacks can be sustained and

See also Peoples National Bank \& Trust Co. of Pemberton v. Bichler, I15 N. J. Eq. 617, 172 Atl. 207 (1934); Matter of Clark, 257 N. Y. 132, I77 N. E. 397 (193I); Matter of Balfe, 245 App. Div. 22, 24, 280 N. Y. Supp. 128, 130 (2d Dep't 1935).

${ }^{20}$ For some discussion of this subject, see Parker, Holding of Close Corporation Securities in Trust Accounts, The Trust Bulletin, February, 1948, p. 24; McHenry, Successful Operation of Business Enterprises as Executor and Trustee, The Trust Bulletin, October, 1947, p. 30. In the District of Columbia the law grants the probate court discretionary power to authorize a fiduciary to continue the business of a decedent for a period of 12 months. 
overcome. The second is a period of maturity, a time for consolidating and protecting the fruits of previous effort, when concern for the continued security of dependents replaces the risk-taking of younger years. Now maturity has its place in nature and in human associations; it comes to every individual and every organism. It is interesting, and perhaps not without significance, that the English, from whom we inherited much of our common law, have a great history and a great reputation as risk-takers and adventurers. For centuries they have roamed the world, and for many years ruled large parts of it; even in modern times perhaps no other nation has been so global minded. Yet when they came to invest their trust funds, to preserve the fruits of their labors, they established the conservative practices which passed over into our own early legal lists.

This idea of "a time to sow and a time to reap" has been developed in eloquent detail by Mr. Louis Headly ${ }^{27}$ in addresses before the Mid-Winter Trust Conferences in New York in 1949 and $195^{\circ}$, in which he emphasized the historical fact that in this period of maturity and consolidation, this period for harvesting and "gathering into barns," prudent men over the years have turned to the trust device. And they have done so because of their deep desire for security-security for themselves or for their dependents. Now we must be careful of this word security. Of late it has taken on some unfavorable connotations, and has come under suspicion, as suggesting a loss of vigor and ambition, if not something worse. But we must not confuse the thing itself with the means by which it is sought. "Go to the ant, thou sluggard" still no doubt is good advice, even among critics of a welfare state. However much we may need and applaud the risk-takers and the doers, the desire for security is basic in our economy and our nature. And in this simple and widely accepted distinction between the years of production and the years of preservation we gain further understanding not only of the standard that is to guide us, but also of the apparent attempt of some of the courts to distinguish between a prudent man and a prudent trustee. That, it appears, is not the real distinction, which lies, after all, just where Justice Putnam said it did-namely, between two different phases of a prudent man's activities. And it is when he is interested in conservation, not acquisition, that he is to be our guide. Nor does it follow that we need lose the spirit of the pioneer, or that maturity for some must lapse into decadence for all simply because we are reminded that deeds of derring-do had better not be done with other people's money.

The critics of conservation raise another point. Not money value, they claim, but the purchasing power of that money, is the thing to be preserved. We are acutely and justifiably concerned today with the diminished buying power of the dollar, which happens to be just about at its low for the past 150 years. But when we speak of preserving the purchasing power of a trust, or measuring a trustee's performance in terms of purchasing power, we are leaving the known highway for a thorny path through a whole thicket of problems. We shall have a look at those problems a

${ }^{27}$ Trustees or "Gentlemen Adventurers," Trust Bulletin, March, 1949, p. r2, and Trustees as Conservators, Trust Bulletin, March, 1950, p. 15. 
little later, but it will be convenient to discuss them in connection with the broadened investment powers of trustees.

The foregoing comments and citations are set down simply to restate and perhaps rescue from limbo some elementary facts concerning trusts which the temper of the times often tends to overlook. Lest any one think that re-affirmation of some ancient truths means that trusteeship is either static or complacent, we turn now to some of the things trustees are doing in their efforts to keep pace with these troubled times.

II

\section{The Trend Toward Liberalization}

Consider, for example, the accomplishments of recent years in liberalizing the laws governing trust investments. Information supplied by $\mathrm{Mr}$. Charles Orcutt of the Trust Division of the American Bankers Association has reminded us that from 1830, when the Harvard College case was decided, to 1937, a period of ro7 years, only 6 states operated under the prudent man rule, all by judicial decision. Beginning, however, with Michigan in $1937,{ }^{28}$ there has been a veritable parade toward the greater freedom of the Massachusetts rule. In the short space of the past $\mathrm{r}_{4}$ years the total number of states using the rule, either in complete or in modified or limited form, has risen to 33 , with two more permitting trustees a choice between prudent rule and statutory legal list. Of this total, 24 states follow the rule in unrestricted form, with the others moving in varying degrees toward the full freedom of the rule. A notable departure from the legal list group within the past two years was New York itself, ${ }^{29}$ long the great stronghold of the legal list idea. Another of particular interest during the past year was Colorado, ${ }^{30}$ where the state constitution itself had previously prohibited all corporate investments. New York joined the small group of states taking an intermediate position between a mandatory legal list and the full freedom of the prudent rule. Colorado, however, went all the way. These departures leave only ro states which still restrict trustees' investments to bonds or other forms of fixed value investments. An effort to take one other state, Ohio, out of this group failed during the past year when the governor vetoed a bill which had been passed by the legislature. A broad classification of the states into these several groups is appended to this article.

The states which have taken an intermediate position between legal list and prudent rule afford some interesting examples of legislation. With variations, of course, the essence of this legislation is to require a certain portion of the trust, usually the major portion, to be invested in designated statutory legals, with a limited permissive area in which other investments, including stocks, may be selected by the trustee under the general rules of prudence. Sometimes certain standards of selection are applied to stocks, such as earnings or dividend tests, a requirement

${ }^{28}$ Mich. CoMp. Laws \$5555.201 and 704.37 (1948).

20 N. Y. Pers. Prop. LAW \$21.

${ }^{30}$ Cozo. Stat. Ann. c. I76, $\$ 126(4)$ (1935), as amended by Laws I951, H. 272, effective March 29, I95r. 
for registration, and the like. Prior to the amendment of the New York law in 1950, New Hampshire, ${ }^{31}$ Nebraska, $^{32}$ and South Carolina ${ }^{33}$ were already permitting trustees a stated percentage of stocks. The District of Columbia enacted similar provisions in $1949,{ }^{34}$ to be followed in $195 \mathrm{I}$ by New Jersey, ${ }^{35}$ North Dakota, ${ }^{36}$ and Pennsylvania. ${ }^{37}$ The percentage limitations used vary considerably. In Nebraska the total invested in stocks of all kinds may not exceed $5^{\circ}$ per cent of the value of the trust; in South Carolina 30 per cent; in the District of Columbia and in New Jersey 40 per cent.

In New York the total percentage of discretionary investments permitted is 35 per cent, but this percentage must include not only common and preferred stocks but any bonds not qualifying under other provisions of the statute.

This type of legislation has drawn some criticism from extreme advocates of the unrestricted Massachusetts rule. They do not like the idea of compromise. To them, this form of legislation is only "half a loaf," part prudence and part something else. This criticism is hardly accurate or fair. There is no compromise with the principles or the precepts of prudence; the only concession is as to the degree of free choice to be permitted by law. The New York and New Jersey statutes, for example, specifically recite in their opening paragraphs, in some of the classic phraseology of the rule itself, that all investments are subject to the overriding rule of prudence. That the statutes go on to designate, and in some cases to set standards for some of the investments to which the rule applies, leaving others to be selected by the trustee, does not at all relieve the trustee of the obligations of prudence with respect to any of the investments authorized under any section of the statutes.

Although the practice is not uniform in all jurisdictions, it might be noted too, with respect to this claim of part prudence and part something else, that in some states which have operated under an official legal list, such as New York, the courts have held that mere selection from an official list does not automatically give immunity from surcharge or criticism, or relieve a trustee from a duty to use prudence. $^{38}$ For example, in Delafield v. Barrett" the court stated that "the fiduciary who invests in securities within the specified classes is not by the statutes free from liability for resultant losses if he fails to exercise reasonable judgment and discretion in making the investment." The revealing analysis of the record of the official New

${ }^{31}$ N. H. Rev. LAws c. 363 , $\$ 7$ (I943), as amended, Laws 1949 , c. I34.

32 NEB. REv. STAT. \$24-60I (Supp. I947).

${ }^{33}$ S. C. LAws $\$ 905 I$ (1942), as amended, Laws 1948, Act 756, and Laws 1951 , Act 350 .

${ }^{36}$ D. C. Code (1940), Rule 23, Rules of U. S. District Court for D. C., Local Civil Rules.

${ }^{98}$ N. J. StAT. ANN. \$3: I6-I (Supp. I950), as amended, Laws I95I, S. B. 274 and S. B. 24.

${ }^{30}$ N. D. Rev. CODE \$6-05I5 (1943), as amended, Laws 1951, H.B. 700.

${ }^{37}$ PA. Stat. ANn. tit. 20, $\$ 821.9$ (1950), as amended, Laws r95x, Act 340 .

${ }^{38}$ One state where this apparently is not the rule is Virginia. See Powell, The Virginia Prudent Man Rule of Trust Investments, 34 VA. L. REV. 102 (1948).

${ }^{59}$ Delafield v. Barrett, 270 N. Y. 43, 48, 200 N. E. 67, 69 (1936). See also Matter of Frazer, I50 Misc. 43, 268 N. Y. Supp. 477 (Surr. Ct. r933); Matter of Blake, I46 Misc. 780, 263 N. Y. Supp. 3Io (Surr. Ct. I933); Durant v. Crowley, 197 App. Div. 540, 189 N. Y. Supp. 385 (Ist Dep't I92I), aff'd, 234 N. Y. $58 \mathrm{r}$, I38 N. E. 455 (1922); and United States ex rel. Willoughby v. Howard, 302 U. S. 445 (1938). 
York list made by the Trust Investment Study Committee of the New York State Bankers Association amply demonstrates the reasons for such a view.

The committee which prepared the New York legislation had carefully considered a number of possible alternatives to the existing legal list, including the full prudent rule, before deciding to recommend the form of law finally enacted. That committee realized that a percentage limitation of the kind mentioned is not ideal and presents certain operating problems. Yet our laws are full of many kinds of percentage limitations, applicable to investments for other types of investors such as savings banks and life insurance companies. None of the objections brought against such a law is insurmountable, and its advantages are numerous. Even without legal compulsion, diversification is common practice. Furthermore, the New York committee, no doubt like other committees in other states, was faced with a practical and political as well as a theoretical problem and it seemed in the interests of fiduciaries to be realistic rather than stubborn.

To be sure, to an advocate of the full prudent rule, legislation of this restrictive type represents something in the nature of "half a loaf." But would a starving man refuse even that? Need we be like a petulant child, who refuses one piece of candy because he can't have the whole bag? After all, what is wrong with compromise? Sometimes it is at bottom nothing more than moderation, one of man's oldest virtues. It has its legitimate uses, as every business man, every lawyer, every diplomat knows. It is not compromise itself, but what, with what, with whom, and for what purpose we compromise, that determines whether it is justfiable. The world will be a more difficult place when and if we lose the art of justifiable compromise. What a statute of this type does do, is enlarge the range and variety of investments, while retaining a requirement for investment of a portion of the trust in sound bonds. Until greater latitude can be won, the latter seems a reasonable price to pay for the former.

A point that sometimes arises in liberalizing an investment law is whether the change should apply to existing trusts. Even those who favor broadened powers for future use are sometimes reluctant to make them retroactive. Their argument is that this in effect is to rewrite the will or trust instrument. Here it is difficult to lay down any hard and fast rule. It must always be understood that the terms of the individual instrument will govern, subject of course to control and construction, if necessary, by the court of proper jurisdiction. But where there is no conflicting language in the instrument, it seems unrealistic not to make amendments applicable to existing trusts. Most of the states which have liberalized their laws over the past decade, have specifically provided that the amended statutes would apply to existing trusts. Others have left the matter to the courts. In jurisdictions where frequent accountings are the rule, it may be useful to ask the court for a ruling at the time of filing an accounting. When the New York law was amended in I950, no special provision covering its applicability to existing trusts was included, but the argument was made that previous amendments had been retroactive where there was no conflict 
with the language of an individual instrument, and in addition there was ground for the view that this was already the established attitude of the courts. In Matter of Hamersley, for example, Judge Delehanty declared that "the trustees had the power to make investments in any securities authorized by statute effective at the date of the investment, whether such statutory authorization was extant at the date of the will or not."40

Finally, as effectively argued by the New York committee, unless these changes in investment laws apply to existing trusts limited to legal investments, there is no relief to the very beneficiaries who need it most. Studies made by the New York committee and confirmed by reports from many parts of the country indicated conclusively that the vast majority of new wills and trust instruments are being written with broad investment powers. Even for the future, however, a reasonable and realistic law will protect those who, from choice or through ignorance or accident, are brought under its provisions. It should be remembered that many wills are silent as to investment powers, and here prevailing law must govern. Others may include restriction to legal investments more as a habit of draftsmanship or as a matter of general policy, without too great investigation or understanding of what such a provision means. The result is often an unfortunate and unintentional restriction.

Along with this trend toward broadened investment powers, and over approximately the same period of time, has come another even more striking, and in some ways a revolutionary development. This is the growing use by corporate trustees of common trust funds. It is revolutionary because it runs counter to the long established legal principle that trust assets should not be mingled. For this reason, more concerted legal effort was necessary to make them possible. Courts, legislatures, and bank supervisory authorities had to be satisfied that the funds could be properly set up and administered. Not only was it necessary to obtain amendments to the federal tax laws, ${ }^{41}$ so that these funds would not be taxed as corporations or associations, in order to avoid double taxation, but enabling statutes had to be passed in the several states, and the Federal Reserve Board, which had issued regulations governing trust operations of national banks which in effect prohibited common trust funds, had to be persuaded to amend its Regulation "F" to cover operation of these funds. Since the exemption of common trust funds from federal corporate taxes is limited to those operated in accordance with the Regulations of the Board of

${ }^{10}$ In re Hamersley's Estate, 152 Misc. 903, 909, 274 N. Y. Supp. 303, 310 (Surr. Ct. I934). In Hollenbach v. Born, 238 N. Y. 34,143 N. E. 782 (I924), a statute authorizing an administrator with the will annexed to exercise a power of sale was held applicable to the estate of a decedent whose will had been probated prior to the enactment of the statute. In Mersereau v. Katz, I97 App. Div. 895, I89 N. Y. Supp. 847 (2d Dep't I921), affd, 233 N. Y. 540, I35 N. E. 909 (I922), and in Matter of O'Donnell, 221 N. Y. 197, 116 N. E. roor (I9I7), laws authorizing the Supreme Court to empower trustees to mortgage or sell real property were applied to estates already in existence at the time the laws were adopted. The constitutionality of such statutes was upheld in. Matter of West, $289 \mathrm{~N}$. Y. 423, 46 N. E. 2d 50I (I943), aff'd sub nom. Demorest v. City Bank Farmers Trust Co., 32I.U. S. 36 (I944).

${ }^{11}$ INT. REV. CODE $\$ 169$. 
Governors of the Federal Reserve System, the effect is to make these regulations applicable to all common trust funds. All of this required time and careful negotiation. It is not necessary to tell here the story of how these obstacles were overcome, but the development of the common trust fund, although limited to institutional trustees, is a definite part of the efforts of trustees in recent years to improve their techniques and their service.

Common trust funds are designed especially to serve the smaller trusts. By centralizing investment supervision, making possible more frequent review and broader diversification, better results should be obtained. There are also savings in operating costs, enabling trust institutions to accept and administer trusts of smaller size than would be practicable otherwise. Although one usually thinks of a trust fund as of substantial size, and some of them do represent very large fortunes, in so far as figures are available (and there are none at all for individual trustees) they indicate that by far the larger number of trusts handled by corporate trustees are of surprisingly small size. A survey made some years ago by the Trust Division of the American Bankers Association indicated that more than half of all trusts administered by trust institutions- 54 per cent to be exact-had an annual income of less than $\$$ r,200. A little over 73 per cent of the trusts had an annual income of less than $\$ 3,000$ a year, with an average income of only $\$ 788$. Not quite 3 per cent of the more than 144,000 trusts on which the survey was based reported income of more than $\$ 25,000$.

When the Federal Reserve regulation on common trust funds became effective in I937, the maximum participation in such a fund permitted to any one trust was $\$ 25,000$. 42 As common trust funds began to be established and seemed to work well, the limit was raised in 1945 to $\$ 50,000,43$ and again last year to $\$ 100,000.4$ At this writing three states, New York, ${ }^{45}$ Minnesota, ${ }^{46}$ and Pennsylvania, ${ }^{47}$ have raised their own limits to $\$ 100,000$, and Georgia, ${ }^{48}$ interestingly enough, has lifted its maximum to $\$ 150,000$, apparently to be prepared for some further increase in the Federal Reserve maximum in the future.

Though at first slow to take hold, the common trust fund idea, like the enlargement of investment powers, has grown rapidly in recent years. As recently as 1937 only 5 states permitted common trust funds. Today, $3^{8}$ states have authorized them, and at the time this is written more than roo separate funds have been established. Although exact figures are not available, as the funds are still growing, in July of I95I the Trust Division of the American Bankers Association estimated that common trust funds already established held total assets of approximately $\$ 600,000,000$. Information gathered by Trusts \& Estates indicated that this total represented par-

\footnotetext{
12 I2 CODE FEd. ReGs. \$206.17 (I938).

"I6 FED. Reg. I62I (I95I).
"Minn. STAT. $\$ 48.84$ (I94I), as amended, Iaws I95I, c. I65.

${ }^{43}$ I2 CODE Fed. Regs. \$206.17 (r949).

${ }^{47}$ P. Stat. ANn. tit. 7, \$8I9-1 I09 (1950), Laws 1951, Act I62.

${ }^{18}$ GA. Code AnN. \$rog-60I (r933), as amended, laws r951, Act 322.
} 
ticipation by nearly 40,000 individual trusts. A list of the states which have authorized common trust funds is appended to this article.

Common trust funds are of two kinds, discretionary and legal. A discretionary common trust fund has broad investment powers, and is open to trusts with similar powers. A legal common trust fund, as the name implies, is used in states where there are restrictions on investments legal for trustees, is itself limited to such investments, and is operated for individual trusts which in turn are so limited. It is important that the status of a participation in a common trust fund, especially in a legal common trust fund, be clearly established as an entity. Some laws specifically so provide; in New York there are decisions to this effect, ${ }^{49}$ although the only one so far by the highest court dealt with a discretionary, rather than a legal fund. The point is of special interest where a legal common trust fund is used under a law permitting a limited percentage of discretionary investments. Establishment of a participation in the legal common trust fund as a legal investment as an entity avoids any necessity to look through the device of the common trust fund to the securities and the diversification of the securities within the fund.

\section{III}

\section{The Meaning of Liberalization: Trustees, Stocks, and Purchasing Power}

Having looked at some legal landmarks and noted the ground swell toward greater freedom in investments, we may consider for a moment, in the light of what has gone before, the meaning and proper uses of these broadened investment powers. We have already noted that the prudent rule states and legal list states divided early over the use of stocks. And as the principal effect of the liberalized investment laws of recent years is a wider use of stocks, it is here that we may well center our attention.

The principal reasons for the use of stocks have often been pointed out. They were summarized in some detail and with considerable documentation in the report of the committee which prepared the 1950 changes in the New York law. ${ }^{50}$ Briefly they are: (I) increased diversification, (2) increased income, (3) possibilities of growth. Associated with this third reason at the present time is the fear of inflation and a desire for protection against it.

The first two reasons have been thoroughly discussed, are pretty generally accepted, and need little comment here. The first comes about simply because there are a number of representative companies in leading industries with no publicly held debt, so that investment in these important units of American industry is possible only

${ }^{10}$ Matter of Hoagland, 297 N. Y. 920,79 N. E. 2d 746 (1948), affirming 272 App. Div. 1040, 74 N. Y. S. 2d 9 II (Ist Dep't I947), which affirmed I94 Misc. 803, 74 N. Y. S. 2d I56 (Surr. Ct. 1947); Matter of Bank of New York, I89 Misc. 459, 67 N. Y. S. 2 d 444 (Surr. Ct. 1946); Matter of Contimental Bank \& Trust Co. of New York, I89 Misc. 795, 67 N. Y. S. 2d 806 (Surr. Ct. 1946); In re Bank of N. Y. and Fifth Avenue Bank (Estate of Cornelia Prime), Suffolk County, Sur., New York Law Journal, Oct. 2, I95I, p. 699 .

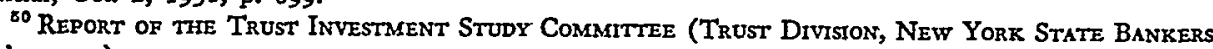
Ass's, 1949). 
by means of stock. With respect to the income argument, perhaps it should be said that an advantage in favor of stocks is normally to be expected, because of their greater sensitivity and non-contractual nature. Also, this advantage needs to be balanced against the regularity and continuity of bond income. Again, as recent wide spreads between stock yields and bond yields have resulted from unusually low bond yields on the one hand and record corporate earnings and dividends on the other, some narrowing of these spreads in the future would not be surprising.

It is the argument for growth, and through this growth a protection against inflation, that produces most of the controversy. It hardly need be said that no one objects to growth, in either principal or income. It is always a pleasant result in any investment. The comments submitted here have primarily to do with some problems involved in the quest for growth, with the attitude of a trustee toward this quest, and with the claim that not money value alone, but the purchasing power of that money, is the thing that trustees should strive to preserve.

Concern over purchasing power is not a new phenomenon. It arises in practically every period of inflation and high prices. Indeed one of the disturbing aspects of the matter is the long record of the varying value of money in the past. And the fate of certain other currencies and standards of value is compelling reason for doing all that we can to preserve the value of our own. But a glance backward may provide perspective, and perhaps even a bit of comfort against some of the more alarmist views for the future.

Chart I shows a record of the purchasing power of the dollar measured against commodity prices from 1800 through 1950 , with 1926 taken as the base year. Several things are worth noting. First of all, the buying power of the dollar at the moment is at just about the lowest point for the past 150 years, hence our acute and justifiable concern. Next, periods of declining purchasing power have accompanied every major war, only to be followed eventually by periods of price deflation and rising purchasing power. It is also to be noted that the buying power of the dollar has been above base value for a far greater portion of the time during the last 150 years than it has been below; also, its buying power was higher at the end of the nineteenth century than at the beginning. There have been long periods of rising purchasing power, which in general have about equalled in extent and duration periods of falling purchasing power. The longest period of declining trend, with only minor interruptions, was from 1896 through 1920 , and was exceeded by approximately 5 years by the previous period of a generally rising trend, from 1865 to 1896 . In view of this 150 year record, and notwithstanding the inflationary pressure all about us, is it yet necessary to assume that there will never again be a turn, even for a time, in the other direction? Moreover, for many investors, including many trustees, it is entirely possible that intermediate swings, of from to to 20 years' duration, may be of more practical-importance than any underlying long term trend. It would be foolish in the extreme not to recognize the seriousness of what is happen- 


\section{Chart I}

Purchasing Power of the U. S. Dolitar

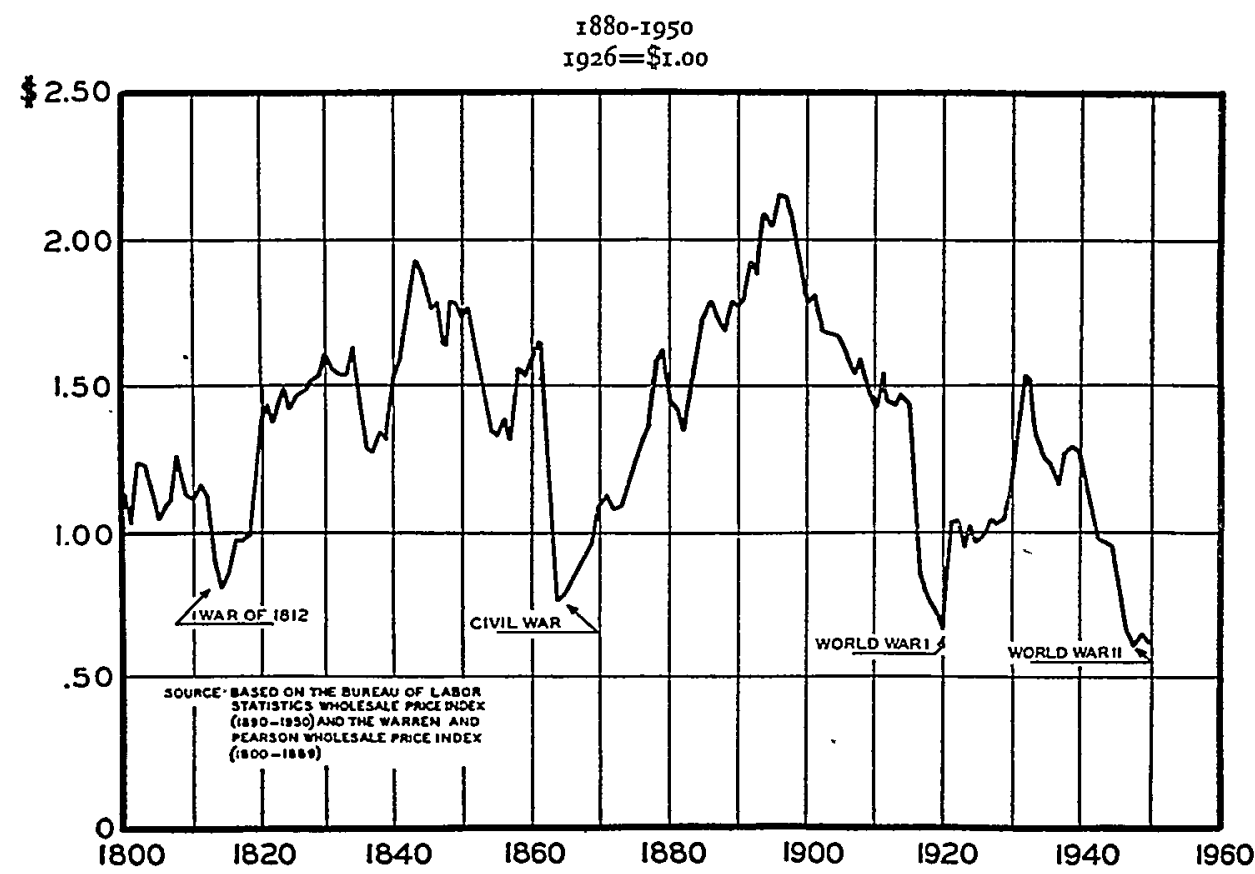

ing to our dollar, but it may do no harm to remember that we have survived cries of calamity before. In 1806 , at the beginning of what was to prove one of the most brilliant centuries in British history, William Pitt, one of Britain's most brilliânt statesmen, said "there is scarcely anything around us but ruin and despair," and near the middle of the same century a despondent Disraeli declared: "In industry, commerce and agriculture there is no hope."

And just as fluctuations in purchasing power are not new, neither are attempts to compensate for them. In fact they are probably as old as the discovery that money can vary in value. Professor Sumner Slichter's recent proposal for a Treasury savings bond payable in purchasing power, or in an increased amount of dollars according to a rise in the cost of living index, is at bottom only a new and modern variant of an old idea. Payment of money contracts in goods, or a modified form of barter, is said to have been used in both Roman and Elizabethan times. We are told that Adam Smith himself toyed with the idea of a standard of value stated in a selected group of commodities, but concluded that it was unsatisfactory. In Revolutionary times Massachusetts actually established by law and tried for several years a so-called "tabular standard" in an effort to cope with its depreciating paper money. Soldiers in the Continental Army had suffered unusual hardship because prices would rise between the time when they were paid in paper money and the receipt 
of this payment by their families. In I780, therefore, Massachusetts passed a law providing for payment of its notes which were issued to soldiers on the following basis: ${ }^{51}$

Both Principal and Interest to be paid in the then current Money of said State, in a greater or less Sum, according as Five Bushels of CORN, Sixty-eight Pounds and foursevenths Parts of a Pound of BEEF, Ten Pounds of SHEEP'S WOOL, and Sixteen Pounds of SOLE LEATHER shall then cost, more or less than One Hundred and Thirty Pounds current Money, at the then current Prices of the said Articles.

The experiment apparently was not satisfactory, and was finally abandoned in 1786 , several years ahead of the time originally set for its expiration.

Perhaps the best known proposal of this kind during more recent times was the late Irving Fisher's "compensated dollar," which he began to discuss actively about I9I3 and had developed in detail by $1920 .{ }^{.62}$ The essence of Fisher's scheme was that the gold content of the dollar would vary according to variations in the wholesale price index. In some of his earlier discussions Fisher argued that the main reason for the failure of previous proposals of this kind was the lack of a suitable index. Whether or not we agree with his assumptions that we now have such an index, it is interesting to recall that he attracted considerable sympathy and approval. ${ }^{53}$ Even those who were most critical of his proposal admitted the care and the skill with which he expounded it, but his scheme never won sufficient support to make any headway at all toward a practical trial..$^{54}$

In times like the present it is easy to forget that periods of rising purchasing power can also bring hardship, but of course to different groups from those affected by falling purchasing power. Producers and creditors, for example, are hurt by falling prices just as recipients of fixed incomes are hurt by rising prices. Low prices, however, are most often associated with depression and low business activity, so that attention is then concentrated upon ways to revive business and increase prices rather than consciously and directly upon ways to decrease purchasing power. And just as periods of falling purchasing power produce proposals and schemes for protection, so too in periods of falling prices do proposed remedies appear. We have already noted the long period of falling prices in the last two decades of the nine-

${ }^{81}$ Willard C. Fisher, The Tabular Standard in Massachusetts History, 27 Q. J. EcoN. 417 (1913) (Harvard Univ. Press).

${ }^{62}$ IRVNing Fisher, Stabilizing the Dotiar (I920).

${ }^{83}$ Among those who expressed approval of Fisher's scheme was President Hadley of Yale. For some dissenting views see Anderson, On the Practical Impossibility of a Commodity Dollar. The Chase Economic Bulletin, Dec. $x_{3}, 1933$, p. 3, and Harry D. Gideonse, The Commodity Doliar (1938).

54 With respect to Professor Slichter's proposal for a "compensated savings bond," certain practical questions seem to arise. Presumably the proposal would apply only to savings bonds, the amount of which for any one holder would have to be strictly limited. Existence of an issue with "built in" protection against inflation would create strong competition for other Treasury issucs. Extension of the proposal to other issues would encounter difficulties of the sort which Irving Fisher himself recognized as arising out of what he called the "great network of contracts binding one generation to the next." There is also a question as to whether the Treasury would benefit from falling prices by being permitted to pay the bonds in lower dollar amounts. 
teenth century. It is interesting to recall that these were the years of bi-metalism and free silver, of William Jennings Bryan and his "cross of gold."

The truth of the matter seems to be that in spite of the efforts of many investors in many places to protect themselves against the falling value of money, so far no magic formula has emerged. What has seemed to work well at one time and place, in one inflation, has not always suceeded somewhere else. Sometimes the effort takes the form of a flight from one currency to another. This method has little appeal today, due to exchange restrictions and the dominant position of the dollar. Exchange of money for physical assets raises the question as to what assets. Gold and commodities, even if the former were available, are impracticable for trustees because they produce no income and involve storage problems. Real property may become unproductive and can invite crushing taxation. But the search for protection continues and stocks provide at least one medium that is convenient and available to all.

Here too, however, the record is not uniformly conclusive. Those who have studied past inflations seem to have found a widely varying performance among different kinds of stocks at different times and places. In no instance do they seem to have provided complete protection. Even in those instances where they provided a measure of protection there has been no uniform pattern. ${ }^{\mathbf{5 5}}$ There have even been instances in which bonds received preferential treatment in revaluation.

Nor is there any close or consistent relationship between commodity prices and stock prices in general. The course for both from $187 \mathrm{x}$ through 1950 is seen on Chart II. ${ }^{66}$ Unfortunately, it is difficult to take the comparison behind $187 \mathrm{I}$, due to meager data as to stock prices for earlier years. Instead of any consistent relationship there are some rather notable periods of divergence. The most striking was during the period from I9I5 to I930, which included the rampant bull market of the late I920's, when stocks rose sharply against a generally stationary trend for commodity prices. It is also interesting to note that stocks failed to follow the sharp rise in

Ev Perhaps the subject has had insufficient study and sometimes satisfactory data are hard to find. For some comment on European experience after World War I see Wright and Henn, Security Prices and Inflation, The Commercial and Financial Chronicle, August 28, 1947, \$2, p. 8. They point out, for example, that in Italy fire insurance stocks seemed to fare best, in Frande texziles, in Austria mining stocks, and in Germany chemicals. The record of all is most uneven and in no instance exactly paralleled commodity prices.

It is often argued too that stocks representing physical assets or commodity values are ideal inflation hedges. But they have not always proved the better market performers. In the last several years the petroleum companies have seemed to bear out this argument, but with high demand for their products and a delicate world supply situation it is hardly necessary to conclude that their performance is due solely to inflation. Other brilliant performers have been the chemicals not ordinarily chosen for inflation protection, and even a stock like General Motors, where high labor costs and the necessity for purchases of large quantities of raw materials would seem to disqualify it as an inflation hedge. More recently the utilities, surprisingly enough, have advanced, although a regulated industry normally stands to be hurt rather than helped by inflation.

to The present Consumers Price Index of the Bureau of Labor Statistics would be a better measure of the consumer's cost of living, but it has been computed for only about half of the time shown on the chart. Also, general commodity prices, representing a wide variety of items, probably are a better refiection of costs throughout the whole economy. 
wholesale prices which began in 1945 and continued through 1948 . For the last year or two both curves have been moving generally in the same direction, although the rate of gain varies considerably.

In observing these movements it will be well to remember also that inflationary periods do not necessarily insure high profits. During the period of inflation there may be rising profits and often increased dividends, but costs eventually become troublesome, and in the deflation which usually follows inventory shrinkages and falling sales may mean serious losses before costs can be brought under control. At the present time high taxes.complicate the picture, but many managements have complained also of rising costs, and interim corporate reports already appearing clearly illustrate the effect of both upon net incomes, notwithstanding record sales volumes. Nor are rising profits and stock prices always due to inflationary influences, for they often accompany normal recoveries and national prosperity.

Even if we plot the two curves of Chart II on the basis of ro-year moving averages, giving both of them a smoothed trend, we find no consistent relationship. This is

\section{Chart 2}

\section{Stocrs vs. Commodity Prices}

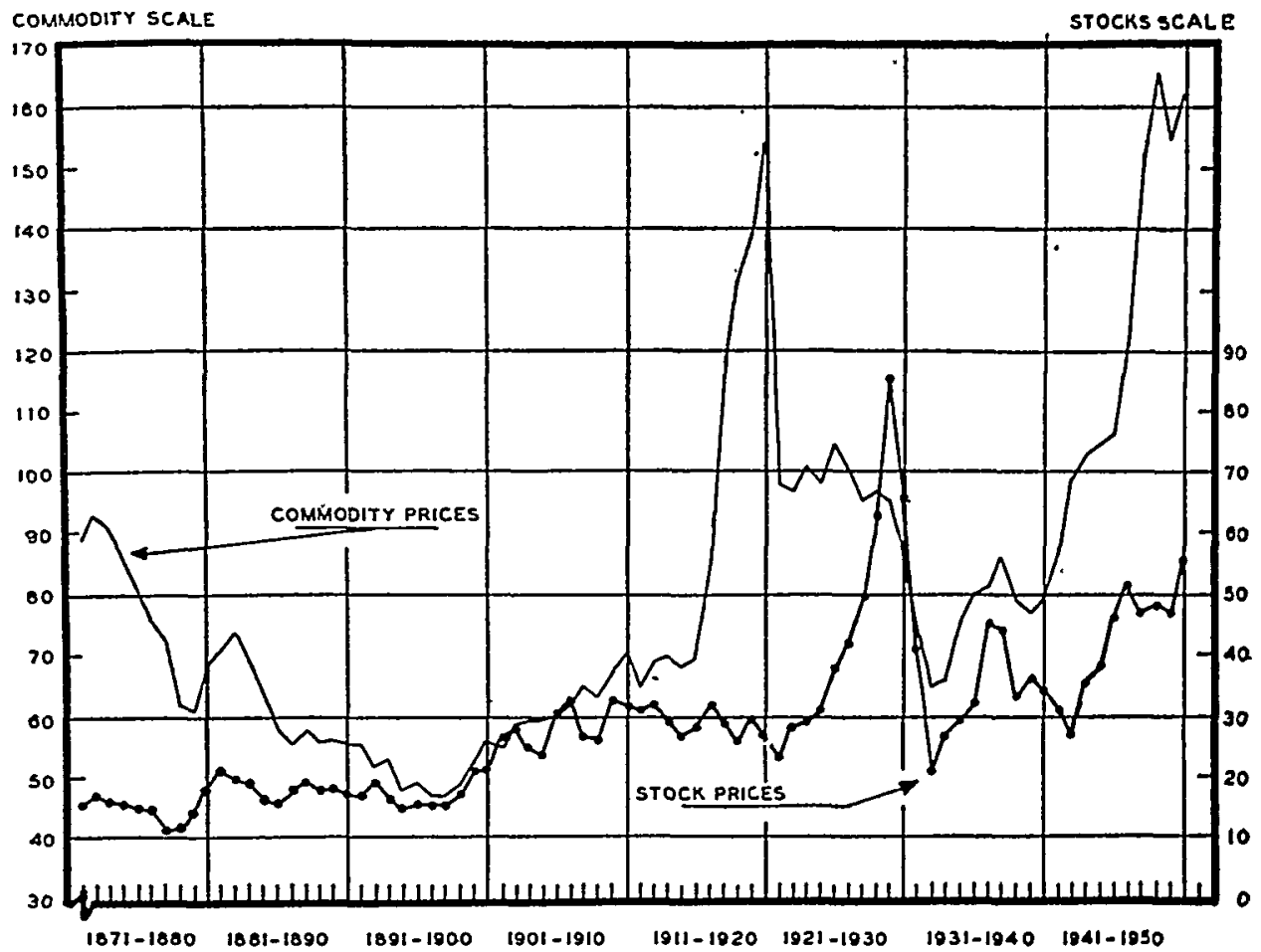

Note: Cowles All Stocks Indexes (avge. for year) used in years $187 x-1928$ after adjustment of $42 \%$ representing the avge. variation between Moody's Composite Stocks (200) and Cowles during the 10 year period 1929-1938. Moody's Composite Stocks (avge. for year) used 1929-1950. B.L.S. Wholesalc Price Index I890-1950; Warren-Pearson Index I800-1889. 
seen in Chart III. True, since about Igoo an upward secular trend is observable in both curves, but not at all in close correspondence between the two. It is interesting to compare this record with some conclusions reached in a study of British share prices from 1870 to $1939 .{ }^{57}$ The British study, which compared stock prices with commodity prices on the basis of 25-year moving averages, found a generally rising trend for stock prices throughout the period, but made the following additional observations: 58

\section{Chart 3}

Stocks vs. Commodity Prices

ro-Year Moving Average I880-I950

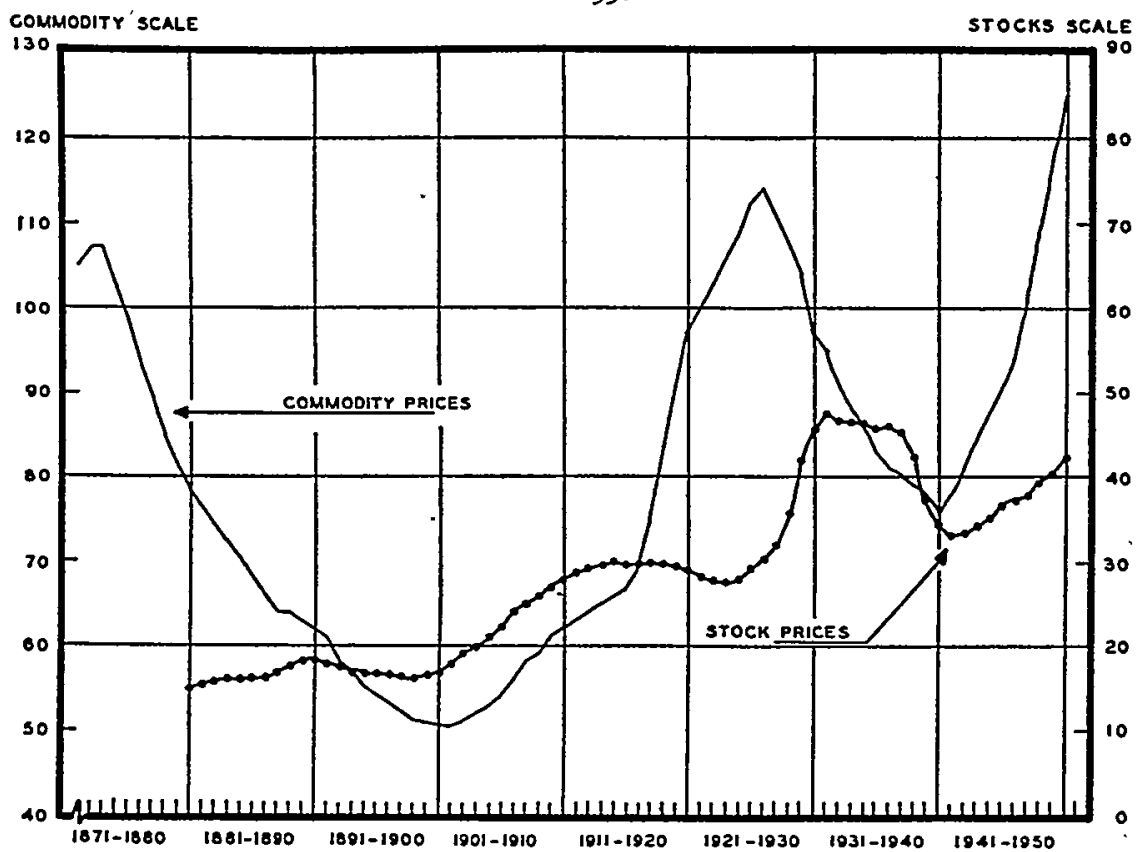

Note: Cowles All Stocks Indexes (avge. for year) used in years I87I-I928 after adjustment of $42 \%$ representing the avge, variation between Moody's Composite Stocks (200) and Cowles during the ro year period r929-r938. Moody's Composite Stocks (avge. for year) used I929-I950. B.L.S. Wholesale Price index $1890-x 950$; Warren-Pearson $1800-1889$.

The long term course of ordinary share values is ascendant throughout. The trend of [commodity] prices for practically half its course is descendant or horizontal. The whole net rise is achieved after the course has passed the middle point chronologically and the rising tendency has petered out before the end. . . . changes of gradient in the price trend do not synchronize with changes in the share trend. . . . Finally, the steepest rise in the share curve is associated with a "stationary" phase of the commodity price curve.

The conclusion to be drawn from the comparison of behavior of the two curves is of particular importance to investors. During the years from 1870 onwards, the rise in share

${ }^{57}$ Hargreaves Parkinson, Ordinart Shares (London, I944) (London, rev. ed. I949).

${ }^{68}$ Id. at 50. 
values outstripped the rise in general prices. Rising equity values, that is the "price" of industrial risk-bearing capital, were not merely a function of the changing value of money.

Comparisons of this kind are helpful only if their purpose is clearly understood. It is not contended that they answer all the questions that may be raised. The object in making them is not at all to say that stocks cannot, or do not ever, afford protection against a rise in general prices. It is simply to highlight the weakness in what seems to be a rather widespread reliance upon some inevitable correspondence between the two.

Next, wholly apart from any question of inflation, it might be noted that even though a long-term growth trend can be established, this does not dismiss the problem. Growth proceeds unevenly from time to time, and among companies and industries. Timing and selection remain of great importance. The Cowles Commission ${ }^{59}$ index of all stock prices indicated an annual average rate of growth of approximately 1.8 per cent from 187 I to 1939 when the study ended. But there are wide and prolonged swings around this long-term trend. And with stock prices, as with commodity prices, in many instances these intermediate swings of reasonable duration can be of far more practical importance than any established secular trend. An average annual rate of growth of about 2 per cent is small comfort to a man who loses a large part of his fortune in a I929 crash. Furthermore, no investor buys or can buy the whole market, or seldom even a whole index, and the importance of selection is easily illustrated.

Out of the Dow-Jones index of 30 industrials, for example, fully a dozen, all stocks of leading companies, could be found which have not participated in the advance of the past $x_{5}$ years. This same index, after 22 years, is still more than 100 points below its high of 1929 , yet $I_{3}$ individual stocks in the index are actually above their 1929 highs. The 195 high to date for this same Dow-Jones index is about 22 per cent above its 1946 high. Yet a recent computation by associates of the writer indicated that if $\$ 100$ had been invested at the 1946 high for the index, in the 30 individual components of the index, I3 of these \$roo investments would at this writing be below their I 946 values, notwithstanding the rise in the general market. ${ }^{60}$

Of course examples could be cited of spectacular growth in individual instances, but stock prices do not always parallel growth in sales, assets or earnings. The railroad industry provides some conspicuous examples. In other industries such outstanding companies as American Telephone, American Can, General Electric, and U. S. Steel are bigger than ever, with sales, net income, and book values all having reached record peaks, yet their stocks are far below previous highs. Again, earnings do not always parallel growth in other respects. Such prominent companies as Consolidated Edison of New York, Chrysler, Texas, and Kennecott have achieved new highs in total revenues, yet their incomes are well below previous highs. The

${ }^{59}$ Common Stock PRICES (Cowles Commission for Research in Economics, 1939).

${ }^{\circ 0}$ In all these comparisons adjustments have been made for changes in the number of shares outstanding. Allowance should be made for market changes since this paper was written. 
25 largest corporations in the country today are not the same ones that were the 25 largest 25 or 50 years ago. A speaker at the Midwinter Trust Conference of I948, discussing the effect upon investments of research and new inventions and emphasizing the rapid changes and criss-cross patterns produced by technological developments, posed the question as to what pattern, if any, emerged to guide investors. "The answer," he said, "is none-except change. Change that will come in greater quantity and in greater variety. Change that will be hard to forecast and difficult to weigh." Ordinary Shares previously referred to. ${ }^{62}$ Although this study reached conclusions generally favorable to common stocks, it inserted a number of cautionary notes, including the following: ${ }^{63}$

At no time in history is it wise to assume that the progress of any nation will continue uninterruptedly, as a matter of course. All history gives the lie to such a complacent belief. The average value of a representative British industrial share portfolio increased, broadly, at a rate of about $2-1 / 2$ per cent per annum during the seventy years between 1870 and r939. No investor, however, is entitled to assume, as a consequence, that if he buys a well-assorted portfolio of industrial shares now and uses every future precaution to ensure that it remains reasonably representative of a changing market, its capital value will inevitably have increased by roo per cent, 200 per cent, or any other given percentage, in half a century's time.

In short, a confident and indiscriminate reliance upon secular growth trends is no proof against disillusionment or disappointment.

In view of the difficulties presented why, it may be asked, do trustees invest in stocks? The answer is found as much in certain general observations as in any particular statistics. Stocks have become more and more an accepted part of the investment field and the capital markets. Information about them and facilities for studying them are more extensive than ever before. The markets in which they are traded are more firmly regulated and less subject to the deliberate manipulation which at times in the past gave them risks wholly unrelated to investment values. For those who want the rewards, and the risks, of ownership, they offer a wide variety of opportunity for participation in the fortunes of American industry. They have their own characteristics, and it is for these that they are bought by understanding investors. But it is important that they be bought for what they are, and not for something else. As the New York committee stated, the form of an investment alone should not be the sole determinant of its usefulness. Neither should the need

\footnotetext{
${ }^{\circ}$ Soule, Research and New Inventions: Their Effects on Investments, The Trust Bulletin, April, I 948 , p. 9 .

2 Parkinson, op. cit. supra note 57, at 255 (1944 ed.).

${ }^{\text {os }}$ Of possible interest as a comment on the present scene is the concluding paragraph from Marriner Eccles's recent book: "Even in our own country we face an ironic paradox. The economic and social problems that are glossed over during a period of defense production or war will come to the fore with increasing severity if we at last attain the sought-for world at peace. How fully to produce and distribute our abundance under conditions of full employment within the framework of our free-enterprise system will continue to be the great challenge for future generations." Marriner S. Eccles, Beckoning FronTIERS 499 (I95I).
} 
for discrimination and continued watchfulness disqualify an investment or deter a trustee from using it. Few investments are "foolproof." In the well-worn words of the Harvard College case, the capital is always "at hazard." The problem for all investors, including trustees, is to find the appropriate program, the appropriate securities, or the appropriate combination of securities, for the purpose to be served. And as purposes vary, so will programs vary. In the confused and tangled scene around us, there is no substitute for careful analysis, good judgment, and perhaps we should add, an occasional smile from whatever gods watch over the fortunes of investors.

Do these comments about purchasing power, and some proposals for protecting it, begin to throw a little light upon the obligations of a trustee? It seems not without significance that in the long history of trusteeship as we know it, there never has been, and in justice there cannot be, any legal obligation to do what so many prudent men have failed to find a dependable means for doing. And until there is more stability in our economy, or better protection against instability, we should be cautious about assuming as a moral obligation something which neither law nor custom has ever required. Aside from the imperfect record of various attempts at protection, there are certain other practical problems. Whose purchasing power is to be preserved, the life tenant's or the remainderman's? Fluctuations in purchasing power and market values are often in different directions. A remainderman is not always interested in the purchasing power of the beneficary. Issues with growth characteristics often yield little income, so that a life tenant may not wish to wait years before principal appreciation is available to produce more income. Would a trustee's performance be measured in terms of a price index? A dollar is at least the same dollar to every holder, regardless of what it is spent for or what taxes it pays. The components of a composite price index may or may not be of equal importance to different persons. Money obligations and assets expressed in money values normally constitute the corpus of a trust. Therefore, wherever it is customary or desirable to judge a trustee's performance in terms of some external measure, why substitute for the legal unit of currency a composite index which is itself computed in terms of money?

Falling purchasing power hurts all recipients of fixed incomes. Protection comes to some through normal salary increases, and certain workers in industry are further protected though escalator clauses in wage contracts based on the cost of living. Salary increases, however, are paid from the earnings of active businesses, whose object is to make money and to grow. The situation is somewhat different with a trustee, working with a fixed amount of money which he must endeavor to preserve. As we have already seen, there are limits to what he can hope to do. "There is no principle upon which a person who is vested with the title to property as trustee for a particular purpose can be authorized to invest it in speculative adventures and no case has been cited or has been found which authorizes such a disposition." ${ }^{\text {a }}$ We shall

\footnotetext{
"English v. McIntyre, 29 App. Div. 439, 5I N. Y. Supp. 697 (Ist Dep't r898).
} 
not attempt here any precise distinction between speculation and investment. Often the line is thinly and faintly drawn, but any doubts must be resolved in accordance with the judgments of the cases and the motives of prudent men looking to a permanent, not a temporary or a venturesome disposition of their funds. But although he must disregard the "optimism of the promoter" and "eschew the exuberance of the speculator," a trustee is not, of course, excluded from the gains which come with economic growth and national prosperity to those enterprises which have established themselves in the confidence of investors. In the words of the New York committee, "in so far as he is a partner in sound enterprise, to that extent, provided he is diligent and prudent in his partnership, he may look forward to a partner's ultimate rewards."

The indictment on the score of purchasing power is not against trustees or the securities they purchase. It is rather against our larger failures in the whole field of politics and economics, the continuing stupidity of war, and everything that contributes to the chronically cyclical nature of our economy. Let no one suppose, however, that trustees are indifferent to the pinch of low income and low purchasing power. It is to do something about it that they have been seeking greater latitude. This, in essence, is the meaning of the liberalization of investment laws which is taking place all over the country-to increase the range and flexibility of their selection, to untie their hands and give them more freedom of action to protect themselves and their beneficiaries from the shocks and surprises of a changing world.

There is one type of trust, however, in which the use of stocks deserves a special word. This is the trusteed pension fund. Employee pension plans have grown rapidly during the last Io years, since changes in the Internal Revenue Code in 1942 gave them special impetus. At that time there were probably less than 1,000 plans in existence; today there are nearer ro,00o. Needless to say, these funds have become an important factor in the investment markets. It is estimated that annual additions to employee pension funds are running not far from $\$ 2,000,000,000$ a year, with probably at least half of this amount added to trusteed plans.

Pension plans vary widely in structure and in purpose, in types of benefit, methods of financing, and other details. There are fixed annuity plans, profit sharing plans, terminal payment plans, and so on. The type we have in mind here is a trusteed plan designed to provide fixed annuities stated in dollars, these pensions or annuities determined according to a formula related to salaries or wage scales. Some of these plans carry supplemental benefits, but the fixed annuity is the chief feature.

We are handicapped in discussing pension funds due to lack of accurate and comprehensive statistics. ${ }^{65}$ There seems no doubt, however, that here, as with personal trusts, there has been a definite swing in recent years toward a wider use of common stocks. Earlier thinking on investments for pension trusts ran heavily

\footnotetext{
${ }^{05}$ Two studies of the pension field are now in progress, which it is hoped will develop useful information, one by the Brookings Institution and one by the Twentieth Century Fund. The results are not available at this writing.
} 
toward fixed income securities. This was due to their distinctive nature and purpose.

Experience with a number of plans prior to World War I had demonstrated the importance and necessity of a sound actuarial basis and adequate reserves. Pension plans are constructed upon certain actuarial assumptions. One of them is that annual contributions over the active service of the employee, invested at an assumed rate of interest, will accumulate the necessary reserves. It is customary and desirable, at regular intervals during the growth of the plan, to test actuarial assumptions and compute an actuarial valuation, to determine whether accumulating assets are abreast of estimated pension liabilities. It follows logically in a plan of the sort we are discussing that stability of the principal and income of invested assets is an important contributing factor. Naturally, therefore, securities with fixed rates of interest and fixed maturities lend themselves ideally to such a plan; further to insure the adequacy and soundness of reserves, the securities used should be of high quality. The general point of view was reflected in a study by the Committee on Employee Trusts of the American Bankers Association. Discussing the conclusions of the study the Chairman of the Committee stated in $1945:^{63}$

The study moreover took pains to emphasize the need of conservatism in the selection of securities for invested plans. The trustee should seek to obtain as much income as is reasonable under market conditions as they exist from time to time, but this should be secondary. It should counsel against actuarial computations based on a yield so high that the trustee is forced to endanger the principal in efforts to carry out a too ambitious income program.

The trustee should never lose sight of the fact that employes' trusts are primarily for the purpose of providing for the welfare of employes and their benficiaries after the earning power of the employes diminishes or ceases.

The study urges prudence and the setting of investment sights along truly conservative lines to safeguard this welfare always irrespective of the latitude given the trustee under the investment powers in the plan or trust agreement.

These comments may serve as a starting point from which to consider the trend of more recent years. There are several reasons for the increased use of stocks in pension trusts, among the more important of which are the following.

(x) The very low yield of recent years on high grade, fixed income securities and the wide spread between this yield and common stock yields, as already referred to earlier in this paper;

(2) the rapid growth of pension funds and the pressure of this investment demand upon the high grade bond market;

(3) the growing costs of pension funds and the desire of managements to finance them as economically as possible.

With the principle of compound interest at work, the rate of return used in a plan can be a vital factor. Therefore, it is probably a fair statement that it is the better

"Activities of Committee on Employees's Trusts, Journal of Commerce and Commercial, May 15, 1945. 
yield from common stocks that has been most important in winning them acceptance as suitable investments for this type of fund. It has been estimated that an increased earnings rate of around $1 / 2$ of I per cent will mean a reduction in the ultimate cost of the plan of from I2 per cent to I4 per cent. Therefore, in these days of rising wage and other costs employers and employees are naturally interested in getting as much as possible from their money. The use of stocks, however, variable as to both market value and income, and having no stated maturity, increases the possibility of instability in both principal and income. Nevertheless, even after allowance for dividend variations, considerable evidence can be adduced to the advantage of stocks on grounds of better average income over a period. The big question arises over possible market fluctuations in a fund of this kind. True, at present the customary practice in using stocks is to value them for actuarial purposes at cost, ignoring market fluctuations. There is still some question, however, as to whether this is necessarily the best method, or will always be the customary and approved method. It is true too that in many funds no liquidation of principal is expected for many years, so that there is no present likelihood of forced liquidation in a depressed market. But a more important argument, and one often advanced to justify their use in this type of fund, where accumulating assets are held against actuarially computed liabilities, is the unusual opportunity for dollar averaging. The annual contributions give them a distinct advantage in this respect over a closed fund.

This advantage is shown graphically on Chart IV, which compares market values as a percentage of book cost of several hypothetical funds from I929 to I950. The solid line plots the value; as a percentage of cost, of a fund based on investment of equal annual amounts during the period, with reinvestment of annual dividend income in additional stocks. The broken line plots the same percentage value of a fixed fund invested in I929, with no subsequent principal additions, but with reinvestment of annual income. The dotted line shows the value of an original fixed principal investment, excluding any reinvestment of annual income. Note the superior performance of the top line, and note that the bottom line, with no averaging of any kind, had not after $2 \mathrm{I}$ years recovered its original value.

Few pension funds, however, and certainly few trusteed plans designed to provide fixed future annuities, will be invested altogether in stocks. ${ }^{67}$ The more customary program would involve a mixture of stocks and bonds, the proportions varying with the circumstances of the individual fund. Although exact information is not available, it seems to be true that in the vast majority of funds where stocks are used, they constitute the smaller portion of the fund. They provide the extra income and the major fluctuations, with reliance upon the larger investment in bonds for stability. An illustration of a hypothetical fund of this kind is shown in Chart V. Here a fund is assumed to have started at the end of 1929 and continued through I950 with

\footnotetext{
${ }^{67}$ There are some exceptions in plans other than those of the fixed annuity type. A notable one is the Sears Roebuck plan, which is invested in the company's stock and at last reports held around $23 \%$ of the total issue.
} 
Chart 4

\section{Three Hypothetical Funds}

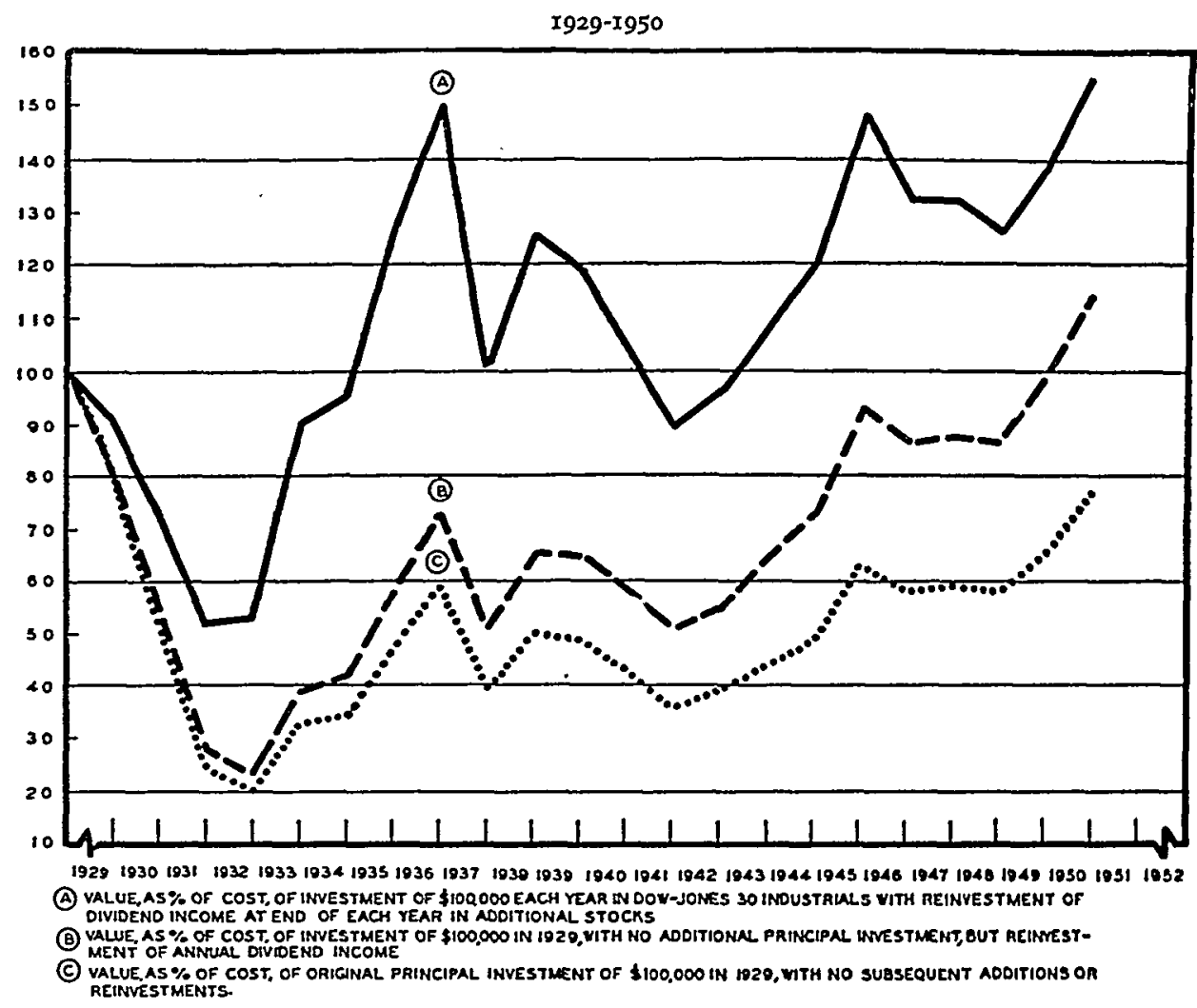

annual increments, including income, invested 20 per cent in Dow-Jones industrials and 80 per cent in Moody's Aaa corporate bonds. These percentages are chosen simply for illustration. . For simplicity the bonds are taken at par throughout the period, although annual investment in bonds is made at prevailing yields. The justification for taking bonds at par is the generally rising trend of bond prices due to declining interest rates during the period covered. ${ }^{68}$ The fluctuation of the stock section of the portfolio is clearly shown, as well as the heavy stabilizing influence of the bonds. The combined value, of course, is the thing that counts against the fund's liabilities, but pension trustees and managers will want to follow closely the performance of all sections of the portfolio.

To this diagrammatic demonstration certain observations should be added. First, the-very emphasis placed upon dollar averaging implies an expectation of some declines against which protection is desired. Next, such a plan must be followed systematically. Failure to make purchases at low prices will seriously interfere with

${ }^{88}$ Calculations to adjust for maturities and refundings affect cumulative bond yields rather than principal values. 
Chart 5

Equal Annual Investment r929-1950

$80 \%$ Bonds, $20 \%$ Stocks

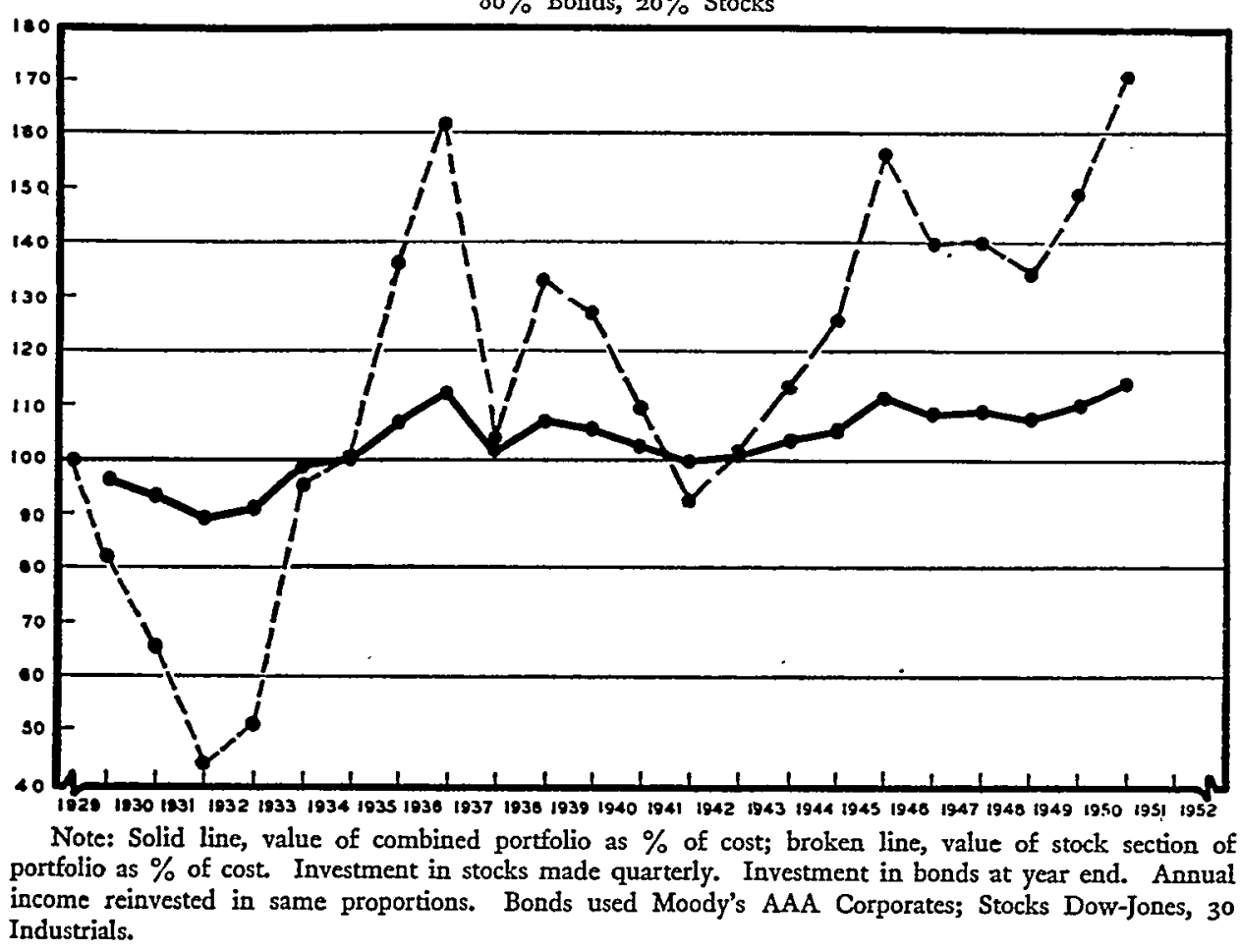

satisfactory results. This raises an important question as to whether management will have the means, and trustees will take the decision, to continue purchases in the face of corporate losses and declining markets in anticipation of an ultimate upturn. Continued buying under such conditions also raises a subtle question touching upon the use of that judgment and discretion required of prudent men, for continued buying in the face of adversity is justified only on the basis of a solid faith in the precedent of an eventual upturn. Perhaps the answer, at least in part, is the fact that so far such plans have worked well; in fact of all of the formulas for stock investing of which we have heard so much of late, the principle of dollar averaging is simplest in application and seems most likely to produce satisfactory results. A further question, of not much more than academic interest at the present time, will eventually arise when funds now using dollar averaging come to maturity. Whether maturity happens to coincide with high markets or low markets would seem to have an important bearing on future investment policy. A more immediate question arises concerning possible withdrawals during depression years. It is sometimes argued that in poor years employment would fall, so that required employer contributions would also fall. But severance may involve substantial withdrawals from the fund, just at a time when they are most disadvantageous. Some funds 
make a practice of investing all employee contributions, if any, in United States Government securities. Dollar averaging can be used to good advantage in pension trusts, but here again there should be no bland assumption that a present mathematical calculation has solved all future questions and insured only a brilliant result.

Although the charts do not show income, it can be stated that the hypothetical fund on Chart $\mathrm{V}$ shows a cumulative yield advantage over an all-bond fund. This advantage is reflected naturally in the final over-all result. During the first 6 years of this hypothetical fund, the yield advantage was with bonds, but about 1936 stock yields began to move ahead and thereafter maintained a distinct advantage, giving the combined portfolio better than an all-bond yield. It should be remembered, however, that throughout most of this period interest rates were declining and corporate earnings and dividends were increasing, resulting in the last several years in an unsually wide yield spread between stocks and bonds.

We should be cautious about projecting these spreads too far into the future. Bond yields apparently have already passed their low point, whereas corporate earnings and dividends may have passed their high point. Moreover, with many of the pension funds established in recent years using actuarial rates of $2-1 / 2$ per cent, and with the yield from Moody's Aaa corporate bonds having increased to around 2.95 per cent from about 2.66 per cent in $195^{\circ}$, it is easier to meet and even exceed actuarial requirements through very conservative programs, so that stocks begin to lose some of the strong income appeal of recent years.

The argument for growth is also used in support of stocks for pension trusts. In these funds, however, even more than elsewhere, it seems to carry somewhat less conviction than the income argument. The annuities which pension trusts provide are not to come into effect for many years, and no one knows what the purchasing power of these future pensions may be. In the type of plan we are here considering, contributions are made right up until the time of retirement, and these contributions will be based upon the employee's salary or wages. In some plans the measuring compensation is the average compensation for a stated period of years prior to retirement. It would seem, therefore, that the proper place and method for protecting the purchasing power of the pension provided by such a plan is through the compensation on which a pension is based. Salary increases through the long period of active service tend to bring the purchasing power of the pension into closer relationship with that of previous compensation.

Of course there is the type of plan which is not scaled to salaries or wages, but in which the employer simply agrees to contribute a stated sum of dollars per year, usually based upon a payment of so many cents per hour per worker. Here particularly there is a natural desire to obtain from the stated contribution the maximum amount of benefit. But it will be well to remember the old difficulty of extracting blood from a turnip. There is a limit beyond which conservative investment policy will hesitate to go, either for extra income or for possible growth. ${ }^{60}$

\footnotetext{
${ }^{89}$ See note 66 supra.
} 
Some managements have placed much emphasis not only upon the importance of obtaining an average yield over and above actuarial requirements, but also upon possibilities of profit in order to be in a better position to meet demands for increased benefits which may come in the future. We have already offered a few thoughts as to the inevitability of further declines in purchasing power as well as the inevitability of profits, but in addition it is important to remember that treatment of extra interest earnings and principal appreciation must proceed in accordance with present and future Treasury Department rulings. Questions may arise, for example, as to the valuation and ultimate treatment from a tax viewpoint of unrealized appreciation in the fund. It may be pertinent to remember that we are as yet in the very early stages of many of the plans established in recent years, and that a number of questions still remain to be determined.

One further comment should be made. It has to do with the essential nature of these funds, and harks back to the duties and limitations of a trustee discussed in the first section of this paper. It has been suggested that these accumulating pension funds are increasingly important sources of capital for American industry. So they are, if properly used. But to regard these funds simply as new pools of investment capital, to be freely tapped for various corporate purposes, is to disregard their nature and the nature of trusteeship. They are trusts, not corporate agencies, irrespective of whether they are contributory or non-contributory, for once trusteed the funds belong to the employees for the purposes of the trust and no longer to the employer. Indeed the primary requirement of Section $I_{6}$ (a) of the Internal Revenue Code, which exempts employees' trusts from taxation, is that such a trust be part of a plan of an employer "for the exclusive benefit of his employees or their beneficiaries." For this reason if a pension fund desires to purchase securities of the employer and still retain its tax exempt status, the regulations require the filing of sufficient information to satisfy the Commissioner that the investment will not violate the above requirement. There is some difference of opinion on this point of investing in securities of the employer corporation, but it is probably safe to say that the majority opinion in the pension field is against it. ${ }^{\mathbf{7 0}}$

Although these comments are devoted primarily to plans of the fixed annuity type, it might be noted in passing that there is some difference of opinion as to investment policy in profit-sharing plans. One school of thought holds that where contributions are dependent upon corporate profits, and therefore made irregularly, once part of the plan they should be invested very conservatively in order to reduce further risks. On the other hand, some argue that the absence of any requirement to pay a

${ }^{70}$ Typical of this point of view is the following excerpt from a study of "Industrial Pensions in the United States" by the National Industrial Conference Board in 1925. In commenting upon a company's reservation of the right to change or abandon a plan, but without affecting pensions, already in force, the study went on to say: "Such a guarantee [continuance of pensions already in force] presupposes, ideally, as a financial sine qua non, an adequate fund invested independently of the business and unaffected by its vicissitudes. For if pensions have to be defrayed, like wages and other current expenses, out of current reserves, they are subject to the same causes of fluctuation and may have to cease during shut-downs or upon dissolution of the business." 
fixed dollar annuity, and the very nature of the plan itself, justify a more aggressive policy. It is difficult to choose arbitrarily or dogmatically between the two views. A decision must be made in the light of circumstances and according to the terms and purposes of the plan itself; what seems appropriate in one plan will not necessarily be appropriate in another.

This paper does not permit consideration of some of the larger problems involved in the growing volume of pension funds and their impact upon the capital markets, or the even larger question as to the ability of the economy to increase its productivity at a rate sufficient to support in inactivity the growing proportion of the population that will be dependent on pensions. Many other questions remain to be solved as pension funds now being established come to maturity and begin to meet the tests of less prosperous years. Meanwhile, within the framework of the special ends they are designed to meet, pension trusts lend themselves to the same intelligent investment planning as other trusts. No one formula will fit every plan. Each one must be studied in the light of its special requirements, its structure, its employee relationships, the tax and financial position of the employer, and even other factors. The ultimate object must be to build into it the greatest possible assurance that it will meet its long range purpose. And the growing acceptance of employee retirement plans as a proper part of an enlightened society opens to trustees another broad field for constructive employment of their special services and experience.

\section{IV}

\section{ConcLusion}

We have come, by a rather circuitous route, to the end of this story. We have hearkened to the counsel of the courts, we have observed the receding line of legislative restriction, and we have called attention to some of the problems involved in use of the new freedom which trustees have won. If these comments have seemed to dwell somewhat lengthily upon some difficult and discouraging aspects of trust investment, it is because so much of the discussion of the day tends to do the opposite. It will profit us little to be beguiled into assuming that our investment problems have become so simple as to be virtually non-existent. These are not times for superficial reliance upon investment by cliché. The freedom of choice and action which trustees are gaining is a call to broadened service and improved performance, through alert and enlightened management, but it implies no authority to ignore the recognized functions of trusteeship or the tested teaching of experience. Perhaps this whole discussion can be summed up and ended in two short observations. The first, having to do with the nature and aims of trusteeship, is the old French saying to the effect that "The more it changes, the more it is the same." And the second, which touches upon the methods of accomplishing these aims, is George Santayana's warning that "Those who cannot remember the past are doomed to repeat it." 
States Following the Prudent Man Rule

$\begin{array}{llll}\text { California } & \text { Kansas } & \text { Minnesota } & \text { Rhode Island } \\ \text { Colorado } & \text { Kentucky } & \text { Missouri } & \text { Tennessee } \\ \text { Connecticut } & \text { Maine } & \text { Nevada } & \text { Texas } \\ \text { Delaware } & \text { Maryland } & \text { New Mexico } & \text { Utah } \\ \text { Idaho } & \text { Massachusetts } & \text { Oklahoma } & \text { Vermont } \\ \text { Illinois } & \text { Michigan } & \text { Oregon } & \text { Washington }\end{array}$

States Whrch Have Moved Toward the Prudent Man Rule Without Adopting It IN UNRESTRICTED ForM

Nebraska

New York

North Dakota***

South Carolina

New Hampshire

North Carolina* Pennsylvania

West Virginia**

New Jersey

Virginia*

District of Columbia

- Permissive states.

- Prudent rule authorized for fiduciaries acting for educational and charitable institutions.

*** Prudent rule authorized for corporate fiduciáries and to extent of 50 per cent of trust.

States Restricting Legai Investments to Bonds

$\begin{array}{llll}\text { Alabama } & \text { Indiana } & \text { Louisiana } & \text { Ohio } \\ \text { Florida } & \text { Iowa } & \text { Montana } & \text { Wisconsin } \\ \text { Georgia } & & & \text { Wyoming }\end{array}$

Nore: The above represents a broad classification. The four states not included in the list-Arizona, Arkansas, Mississippi, and South Dakota-seem difficult to classify in this simplified fashion. It is possible that at least one, Arkansas, should be classed as a permissive state. In every instance reference should be made to the statutes and decisions of the individual states for further information or for changes since the above list was prepared.

\section{States Authorrzing Common Trust Funds}

$\begin{array}{llll}\text { Alabama } & \text { Idaho } & \text { Michigan } & \text { Oregon } \\ \text { Arizona } & \text { Illinois } & \text { Minnesota } & \text { Pennsylvania } \\ \text { Arkansas } & \text { Indiana } & \text { Mississippi } & \text { South Dakota } \\ \text { California } & \text { Kansas } & \text { Missourit } & \text { Texas } \\ \text { Colorado } & \text { Kentucky } & \text { New Jersey } & \text { Utah } \\ \text { Connecticut } & \text { Louisiana } & \text { New York } & \text { Vermont } \\ \text { Delaware } & \text { Maine } & \text { North Carolina } & \text { Virginia } \\ \text { District of Columbia } & \text { Maryland } & \text { Ohio } & \text { Washington } \\ \text { Florida } & \text { Massachusetts } & \text { Oklahoma } & \text { West Virginia } \\ \text { Georgia } & & & \text { Wisconsin }\end{array}$

Source: Trust Division, American Bankers Association.

† By judicial decision 